\title{
IN PRAISE OF FACTION: HOW SPECIAL INTERESTS BENEFIT CONSTITUTIONAL ORDER
}

Jide Nzelibe

\begin{abstract}
Political factions are rarely treated as normatively desirable entities in constitutional or international law. On the contrary, they are either regarded as forces that thwart the general welfare or as sources of chronic political instability. Thus, the conventional wisdom often focuses on how to deploy institutional or legal structures that minimize the influence of faction. By contrast, this Essay argues that the institutions of constitutional and international law that are forged by self-interested factions can create significant side benefits for the rest of the society. At bottom, such institutions are likely to be more durable and energetic than those created by disinterested or high-minded social designers. Thus, rather than focus on trying to curtail the influence of faction in shaping political institutions, it may make more sense to broaden the scope of such influence to be as inclusive as possible.
\end{abstract}

AUTHOR-Professor of Law, Northwestern University School of Law. I am grateful to Daniel Abebe, Daron Acemoglu, David Austen-Smith, William Baude, Stephen Calabresi, Zach Clopton, Josh Fischman, James Gathii, Meredith Johnson Harbach, Aziz Huq, Tonja Jacobi, Andrew Koppelman, Sonia Mittal, Jennifer Nou, Nadav Shoked, Andrew Spalding, Matthew Spitzer, Adrian Vermeule, Mila Versteeg, and participants at the Searle Center Symposium on Institutional Design at Northwestern University School of Law, the University of Richmond Law Workshop, and the International Law Workshop at Loyola University Chicago School of Law for helpful comments on earlier drafts. 
NORTHW ESTER N U N V ER S T Y L A W R E V I E W

INTRODUCTION

I. THE FEAR OF FACTION.

II. Factions May Benefit Institutional Design 647

A. Overcoming Collective Action Problems

B. Generating Spillover Benefits for Other Groups

C. Factions May Safeguard Against the Concentration of Authority

D. Some Cautionary Notes About the Benefits of Faction

CONCLUSION

\section{INTRODUCTION}

A bedrock assumption of democratic theorizing is that if one wants good and enduring constitutional and international institutions, one ought to suppress as much as possible the influence of self-interested factions. ${ }^{1}$ This Essay suggests a contrary view. Take away the role of self-interested factions in institutional design and you risk being left with institutions that are unstable, weak, and lacking in energy. Across a wide swath of issue areas, from international trade to war powers, factions have played a beneficial role in designing and shaping relevant political institutions. At its core, this Essay argues that at least in some critical respects, we may want to encourage a greater-not lesser-role for self-interested factions in the design and maintenance of framework institutions of constitutional and international law.

In many ways, the role assigned to factions in this account is rooted in a reverse Madisonian logic. According to Madison, our structure of separation of powers acts to diminish the role of factions by fueling institutional competition between the political branches in which "ambition must be made to counteract ambition." " By contrast, in the framework espoused here, institutional actors do not operate as a countervailing force against the influence of factions. Instead of being harnessed by other institutional actors, powerful factions will attempt to co-opt these diverse institutional actors to serve their narrow policy and electoral ambitions. But

\footnotetext{
${ }^{1}$ I use the terms "factions" and "special interest groups" interchangeably throughout this Essay. For a review of the literature on how constitutions may constrain rent seeking by interest groups, see Daniel Sutter, Constitutional Politics Within the Interest-Group Model, 6 CONST. POL. ECON. 127 (1995); Jonathan R. Macey, Competing Economic Views of the Constitution, 56 GEO. WASH. L. REV. 50 (1987); and Cass R. Sunstein, Naked Preferences and the Constitution, 84 CoLuM. L. REV. 1689 (1984). The seminal work on this issue includes GEOFFrey BRENNAN \& JAMES M. BuCHANAN, The REASON OF RULES: CONSTITUTIONAL POLITICAL ECONOMY (1985).

2 The Federalist No. 51, at 349 (James Madison) (Jacob E. Cooke ed., 1961).
} 
here is the catch: those self-interested ambitions will often, though not always, overlap with what is socially beneficial for other groups in society.

Overall, the thrust of this Essay's argument is that we should view the private benefits that factions extract from pushing their preferred institutional arrangements as socially desirable. The possibility of obtaining private benefits may spur factions to create and maintain valuable political institutions. To be sure, sometimes the role of factional self-interest in institutional politics can become excessive and counterproductive. The solution should not be, however, to weaken or diminish the influence of factions, but instead to control their undesirable excesses through measures that discourage corruption and arbitrary governance. But having a system where rules are generally enforced "by the book" among major factions does not entail that those rules always have to be fair to all groups in society or enhance the general welfare. Indeed, in many instances, the rules may be skewed in favor of certain groups. This will often prove sufficient for long-term political stability, even if certain factions are favored, provided that the rules do not threaten the interests of the most powerful factions.

The analysis here implies that the preoccupation with overcoming or managing faction has obscured a more fruitful approach to institutional design in constitutional and international law. There is no need to accept the notion that for constitutional democracy to flourish one needs efficient institutions that promote the interests of the majority of voters at the expense of narrow or minority factions. Similarly, international legal institutions need not produce outcomes that consistently advance the general welfare to be politically sustainable and enjoy widespread acceptance. From a normative perspective, what matters is not promoting the general welfare or weakening factions per se. It is instead to further some goals of institutions that may occasionally overlap with efficiency but albeit in an imperfect and somewhat unpredictable manner. One of those key goals includes institutional stability, and the route to that goal may often require that we accommodate the interests of powerful factions in a pragmatic and fair manner, and not oppose them. Indeed, a greater threat to democracy may arise when institutions evolve to threaten the fundamental preferences and interests of powerful political factions, especially when such institutions are perceived to produce policy effects that disproportionately benefit one side at the expense of another.

Framed differently, the logic underpinning stable political institutions is not that they are structures that provide for general welfare; but instead, to borrow a phrase from Hirschman, they are structures of power that 
reflect a compromise among warring factions who "recognize their mutual inability to achieve dominance."3

The argument proceeds as follows. Part I briefly describes the fear of faction in debates in the institutional design literature. Even when theorists acknowledge that purging the influence of self-interested factions in institutional design will not always be feasible, it is often upheld as a regulative ideal to which institutional framers should aspire.

Part II quibbles with the logic underpinning this assumption. It argues that, under the right conditions, self-interested factions do and should play a role in institutional design in both constitutional and international law. First, and most importantly, factions can help overcome some of the collective action problems that are likely to plague both the choice and maintenance of political institutions. Second, factions may invest significant resources in trying to promote the kinds of institutional arrangements under which they will likely secure private benefits. In doing so, they will often embrace institutional features that create spillover benefits for other unorganized groups. Thus, at the level of institutional choice, the crucial dynamic is not the one Mancur Olson feared-organized minority groups exploiting the unorganized majority-but rather, unorganized and passive groups and individuals free-riding off the efforts and investments of organized factions. ${ }^{4}$ Third, factions are likely to act as a countervailing force against the centralizing and collusive tendencies of power holders located in the various political branches and in international institutions. These benefits are illustrated through intense factional conflicts in United States history surrounding efforts to revise the constitutional structures that govern international trade and the allocation of war powers. This Part concludes by recognizing that while the focus of the paper has been on the upside of factions on institutional design, it is also the case that sometimes the influence of factions may not always be beneficial. In other words, there will often be tradeoffs between the energy and resources that factions may bring to the design of political institutions and the risks of corruption or wholesale capture of institutions by factions. But this Essay emphasizes the benign side of the tradeoff because it is one largely overlooked in much of the public law literature.

This Essay then concludes.

\footnotetext{
${ }^{3}$ Albert O. Hirschman, The Rhetoric of ReAction: Perversity, Futility, JeOPARDy 168 (1991).

${ }^{4}$ Mancur Olson, The logic of Collective Action: Public Goods and the Theory of GROUPS 53 (1971).
} 


\section{THE FEAR OF FACTION}

Much of public law discourse is obsessed with overcoming faction. Indeed, disquiet about the role and undue influence of political factions is as old as the American Republic itself. ${ }^{5}$ But while constitutional and democratic theory has been historically preoccupied with the dangers of majority factions, ${ }^{6}$ today's theorists are more likely to be concerned about the influence of well-organized minority factions that supposedly run roughshod over the interests of the majority. Simply put, the feared specter of modern democracy is no longer that mass publics will impose their will on discrete minorities, but that minorities with concentrated interests will oppress majorities with diffuse interests. Mancur Olson undercut the optimistic vision of the pluralists of an earlier era who assumed that competition among interest groups would produce a desirable confluence of the preferences of all groups in society. ${ }^{7}$ Indeed, much of modern public choice theory emphasizes the disproportionate power that narrow groups exercise over public policy. For the most part, theorists assume that the power of minority groups will be deployed for counterproductive purposes.

Constitutional and democratic theorists, who denounce the corrosive effects of narrow factions, are quick to point to a solution: fixing our constitutional structure and international institutions. ${ }^{8}$ And in an ironic twist of events, almost all the institutional actors that were originally supposed to check the tyranny of the majority are now being elicited to stop

\footnotetext{
${ }^{5}$ See The Federalist No. 10, at 55-56 (James Madison) (Henry Cabot Lodge ed., New York, G.P. Putnam's Sons, 1889) ("To secure the public good and private rights against the danger of such a faction, and at the same time to preserve the spirit and the form of popular government, is then the great object to which our inquiries are directed.”).

${ }^{6}$ See id. at 55 ("When a majority is included in a faction, the form of popular government... enables it to sacrifice to its ruling passion or interest both the public good and the rights of other citizens.”); see also JEFFREY M. BERRY, THE INTEREST GROUP SOCIETY 2 (1985) (“Madison's analysis in [The Federalist's] essay No. 10 remains the foundation of American political theory on interest groups.”).

7 See Olson, supra note 4, at 53. For seminal examples of the optimist vision of the pluralist approach to factions, see RoBert A. Dahl, PluRalist Democracy in the United States: Conflict and Consent 23-24 (1967), and David B. Truman, The Governmental Process: POLITICAL INTERESTS AND PUBLIC OPINION (2d ed. 1971).

${ }^{8}$ The seminal account of using institutional design to correct the pathologies of public choice is from Brennan and Buchanan. See BRENNAN \& BuChanAN, supra note 1, at 2 ("If rules influence outcomes and if some outcomes are 'better' than others, it follows that to the extent that rules can be chosen, the study and analysis of comparative rules and institutions become proper objects of our attention.”). One version of this approach assumes that an institutional arrangement that has buy-in from a supermajority will best serve the general welfare. See, e.g., JOHN O. MCGINNIS \& MiCHAEL B. RAPPAPORT, ORIGINALISM AND THE GOOD CONSTITUTION 1-3 (2013) (arguing that interpreting the Constitution according to the original intent will be welfare-improving because it received the assent of a supermajority); see also Rachel E. Barkow, Insulating Agencies: Avoiding Capture Through Institutional Design, 89 TEX. L. REv. 15, 23 (2010) (proposing institutional reforms that would help avoid capture of agencies by interest groups).
} 
the onslaught of narrow minorities. Thus, independent courts, once heralded as beacons of hope for minority groups and the disenfranchised, ${ }^{9}$ are being repackaged as institutional actors that can defend enfranchised majorities against the threat of special interests. ${ }^{10}$ Presidents, once considered aloof and removed from populist sentiments, are now venerated as a bulwark against the parochial factions that dominate the "broken branch" of Congress. ${ }^{11}$ Even independent bureaucrats-those faceless enemies of populism - have been enlisted in the cause to check the dangers of narrow factions. ${ }^{12}$ Finally, international law, often chastised for its democratic deficit, ${ }^{13}$ has also been brought into this picture. As one commentator argued in the context of international trade agreements, “[G]overnments risk to become prisoners of the 'sirene-like' pressures of organized interest groups unless they follow the wisdom of Ulysses ... and tie their hands to the mast of international guarantees ...."14

\footnotetext{
${ }^{9}$ See Bertrall L. Ross II, Democracy and Renewed Distrust: Equal Protection and the Evolving Judicial Conception of Politics, 101 CALIF. L. REV. 1565, 1624 (2013) ("Minorities considered politically marginalized in the Vinson and Warren Courts era and equal partners in the political process in the Burger Court era came to be perceived as having too much political power in the Rehnquist and Roberts Courts era.").

10 See, e.g., BARRy Friedman, The Will of the PeOPle 375 (2009) ("The [Supreme] Court has to be attuned to aroused public opinion because it is the public that can save a Court in trouble with political leaders and likewise can motivate political leaders against it.”); Alon Cohen, Independent Judicial Review: A Blessing in Disguise, 37 INT'L REV. L. \& ECON. 209 (2014) (arguing that judicial review dissipates the power of special interest groups); Jonathan R. Macey, Promoting PublicRegarding Legislation Through Statutory Interpretation: An Interest Group Model, 86 CoLUM. L Rev. 223, 267-68 (1986) (same); Cass R. Sunstein, Interest Groups in American Public Law, 38 STAN. L. Rev. 29, 86 (1985) (same). But cf. William M. Landes \& Richard A. Posner, The Independent Judiciary in an Interest-Group Perspective, 18 J.L. \& ECON. 875, 879 (1975) (arguing that "an independent judiciary facilitates rather than, as conventionally believed, limits the practice of interest-group politics”). Other scholars have questioned whether there is any clear relationship between judicial independence and general welfare. See, e.g., Michael D. Gilbert, Judicial Independence and Social Welfare, 112 МicH. L. REV. 575, 609 (2014).

11 See Jide Nzelibe, The Fable of the Nationalist President and the Parochial Congress, 53 UCLA L. REV. 1217, 1226-30 (2006) (summarizing this view in the legal literature). For a more sanguine view of executive power as a check on congressional susceptibility to faction, see Steven G. Calabresi, Some Normative Arguments for the Unitary Executive, 48 ARK. L. REV. 23 (1995).

12 See, e.g., Mark Seidenfeld, A Civic Republican Justification for the Bureaucratic State, 105 HARV. L. REV. 1511, 1515 (1992) (“[H]aving administrative agencies set government policy provides the best hope of implementing civic republicanism's call for deliberative decisionmaking informed by the values of the entire polity.”).

13 See Jeremy Rabkin, Why Sovereignty Matters 10-21 (1998) (emphasizing the need for stronger constitutional safeguards in the creation of international commitments); John O. McGinnis \& Ilya Somin, Should International Law Be Part of Our Law?, 59 STAN. L. REv. 1175, 1233-46 (2007) (discussing the democratic deficit of certain kinds of international law, including customary international law).

14 Ernst-Ulrich Petersmann, The Transformation of the World Trading System Through the 1994 Agreement Establishing the World Trade Organization, 6 EUR. J. INT'L L. 161, 166 (1995); see also John O. McGinnis \& Mark L. Movsesian, Commentary, The World Trade Constitution, 114 HARV. L. REV. 511, 528-30 (2000) (describing the logic of the World Trade Organization (WTO) as benefitting all countries at the expense of special interest groups).
} 
Many of these prescriptions appear to exploit certain realist aspects of political life, such as the belief that one can mobilize vice (or political selfinterest) in the service of virtue. ${ }^{15}$ In these models, however, the civilizing source of self-interested political behavior tends to run largely in one direction. In other words, the self-interests of power holders will tame the self-interests of factions, and not the other way around. ${ }^{16}$ Avarice or greed are the interests that presumably need to be checked, and an office holder's quest for honor, prestige, and power does the checking. ${ }^{17}$ Of course, powerseekers could check each other, such as when the courts and Congress are presumed to check the President. ${ }^{18}$ But the literature rarely considers the possibility that factions may in turn play a role in checking the excessive ambitions of office holders. ${ }^{19}$ At the most basic level, factions have become the undesired orphans of institutional design.

15 One illustration of such an invisible hand argument is James Madison's famous claim in The Federalist No. 51 that separation of powers will make "[a]mbition ... counteract ambition.” THE FEDERALIST No. 51, supra note 2, at 349 (James Madison). Madison's argument has long been criticized for its opaqueness and lack of clarity. See M. Elizabeth Magill, Beyond Powers and Branches in Separation of Powers Law, 150 U. PA. L. REV. 603, 604-05 (2001).

${ }^{16}$ A radical expression of the view that the pursuit of honor and ambition would ameliorate the habits of greed is put forth by Hamilton in The Federalist No. 72. In his defense of allowing the President more than one term in office, for instance, he argues:

[I]f he could expect to prolong his honors by his good conduct, he might hesitate to sacrifice his appetite for them to his appetite for gain. But with the prospect before him of approaching an inevitable annihilation, his avarice would be likely to get the victory over his caution, his vanity, or his ambition.

THE FEDERALIST No. 72, supra note 5, at 452 (Alexander Hamilton).

17 Indeed, the political theorist, E. E. Schattschneider, thought that parties could serve to allay the pernicious influence of factions for this very reason. See E. E. Schattschneider, Pressure Groups Versus Political Parties, 259 Annals AM. ACAD. Pol. \& Soc. SCI. 17, 17 (1948). For parties, he argued, "[t]he object is ... to exercise the total power to govern and to assume general responsibility for the conduct of public business." Id. Special interests, on the other hand, "do not attempt to get power by winning elections and are exempted, therefore, from the compulsions which determine the nature of party organization.” Id.

${ }^{18}$ Indeed, there is a vast contemporary literature on institutional reform that continues to rely on harnessing the self-interests of power seekers, such as courts or Congress, to correct excessive ambitions of other office seekers such as the President. See, e.g., Harold HonguU KoH, ThE National Security Constitution: Sharing Power After the Iran-Contra AfFair 185-207 (1990) (suggesting elaborate legislative proposals to give Congress more bite in war powers). In addition to constitutionally recognized institutional players, some have also included a role for powerseeking political parties or even broader constraints in the international system as a counteracting agent on other power seekers. See Daniel Abebe, The Global Determinants of U.S. Foreign Affairs Law, 49 STAN. J. INT'L L. 1, 51-53 (2013) (advocating the consideration of external constraints on the President's foreign affairs authority); Daryl J. Levinson \& Richard H. Pildes, Separation of Parties, Not Powers, 119 HARV. L. REv. 2312, 2330-47 (2006) (parties as counterweight). But policy-seeking factions continue to be accorded little or no role.

${ }^{19}$ Ironically, this view is a complete inversion of the vision associated with Hobbes and other eighteenth century political theorists. For such theorists, it was the pursuit of honor and dignity that was considered more damaging to the public order, and he believed the more mundane passions would serve to counteract them. See Albert O. Hirschman, The Passions AND the Interests: Political ARGUMENTS FOR CAPITALISM BEFORE ITS TRIUMPH 31 (1977). 
Here is the rub: If political actors are susceptible to the influence of narrow factions during times of normal politics, how can we be sure they will not fall prey to the same forces when they are designing the institutions that establish the political rules of the game? After all, if political structures influence policy outcomes, then surely the same factions will seek to shape such political structures. ${ }^{20}$ Indeed, Jack Knight has suggested that political institutions are often "not best explained as a Pareto-superior response to collective goals or benefits but, rather, as a by-product of conflicts over distributional gains." 21

But even as theorists acknowledge that purging the influence of selfinterested factions in institutional design will not always be feasible, ${ }^{22}$ it is often upheld as a regulative ideal to which institutional framers should aspire. Jon Elster has argued, for instance, that while there is no sure institutional path to the general welfare at the expense of faction, "constituent assemblies ought as far as possible to remove from their agenda issues on which interest has a purchase." ${ }^{23}$ Otherwise, there is a risk that self-interested actors will exploit the occasion of institutional design to entrench themselves in power or lock in their preferred policy objectives.

Against this view, some have argued that self-interested factions can provide the energy and motivation required to push through crucial policies. ${ }^{24}$ This Essay embraces this traditional justification for faction

20 There is a growing literature on the contingency of political institutions. William H. Riker, Implications from the Disequilibrium of Majority Rule for the Study of Institutions, 74 AM. PoL. ScI. REV. 432, 444-45 (1980) ("[I]nstitutions are no more than rules and rules are themselves the product of social decisions.”); see also Tom Ginsburg, Public Choice and Constitutional Design, in RESEARCH Handbook on Public Choice and Public Law 261 (Daniel A. Farber \& Anne Joseph O’Connell eds., 2010) (discussing the role of power and self-interest in shaping institutions); Terry M. Moe, Power and Political Institutions, 3 PERSP. ON POL. 215 (2005) (same); Jide Nzelibe, Strategic Globalization: International Law as an Extension of Domestic Political Conflict, 105 Nw. U. L. REV. 635, 658-82 (2011) (same).

21 JACK KNIGHT, InSTITUTIONS AND SOCIAL CONFLICT 19 (1992) (emphasis omitted).

22 Although if factions resist having their interests or preferences ignored in institutional reform, then one runs into the problem in which the proposed reform runs contrary to the preferences of the likely reform agent. See Adrian Vermeule, Self-Defeating Proposals: Ackerman on Emergency Powers, 75 FORDHAM L. REV. 631, 636-40 (2006) (discussing this problem in institutional reform proposals).

23 Jon Elster, Securities Against MisRule: Juries, Assemblies, Elections 235 (2013) (emphasis omitted). Other commentators have also expressed skepticism about the relationship between general welfare and institutional design. See, e.g., Adrian Vermeule, The System OF the CONSTITUTION 77 (2011) ("[T] here is no general welfarist argument for the separation of powers or checks and balances.")

24 Adrian Vermeule, Veil of Ignorance Rules in Constitutional Law, 111 YALE L.J. 399, 402 (2001) ("Veil rules not only dampen both information and bias; they also suppress decisionmakers' activity. Removing the spur of self-interest threatens to reduce decisionmakers' activity below acceptable levels, to the point where constitutional designers might plausibly prefer to lift the veil and spur more activity, even if the price is that some fraction of that increased activity is self-regarding."). For a broader defense of the role of social conflict by pressure groups in advancing democracy, see MARTIN H. 
during times of ordinary politics, but expands upon it by showing that it can also be supported by other normatively attractive justifications, even when the ostensible goal is designing framework institutions in constitutional and international law and not simply policymaking.

\section{FACTIONS MAY BENEFIT INSTITUTIONAL DESIGN}

When factions help shape political institutions, they can perform the following key functions: overcome collective action problems in the choice of institutions, create spillover benefits for unorganized groups, and help constrain the self-interested behavior of individual office holders.

\section{A. Overcoming Collective Action Problems}

The overarching point is a somewhat familiar one: Political institutions (such as those that empower and constrain public officials in constitutional or international law) are like any other sort of public good, and because of free-riding problems, there is a risk that they can be underproduced. After all, citizens will benefit from such institutions regardless as to whether they contribute towards establishing them in the first place. So they may likely shirk in contributing their fair share of energy and resources towards institutional design. But this free-riding tendency by citizens can thwart the provision of beneficial public institutions. In this scenario, we might be better off delegating some of the responsibility for both designing and maintaining political institutions to those who clearly have the motivation and resources to do so effectively, i.e., self-interested factions. Such factions may not only supply the relevant energy and resources for ushering their favored institutions through the political process, they also have incentives to alert the public and politicians of the costs and benefits of any institutional alternatives being considered.

The force of this argument has been recognized in other contexts. Cowen et al. invoke it in explaining how groups seeking rents may further beneficial policy outcomes when officials are otherwise not sufficiently motivated. ${ }^{25}$ They argue, "Such institutions as pork-barrel politics can offset the selfishness of public sector participants, because they reward

REDish, THE ADVERSARY FIRST AMENDMENT: FrEe EXPRESSION AND THE FOUNDATIONS OF AMERICAN DEMOCRACY 7-10 (2013).

25 Tyler Cowen et al., Rent Seeking Can Promote the Provision of Public Goods, 6 ECon. \& PoL. 131, 140-41 (1994). There is also a significant political economy literature that suggests that interest groups competition can enhance the quality of public information. See David Austen-Smith \& John R. Wright, Counteractive Lobbying, 38 AM. J. POL. SCI. 25, 28 (1994); Richard Ball, Interest Groups, Influence and Welfare, 7 ECON. \& POL. 119 (1995). 
political effort.” ${ }^{26}$ Arguably, the self-interest of factions has even played an analogous role in the Supreme Court's First Amendment jurisprudence. Justice Scalia, dissenting in Rutan v. Republican Party of Illinois, ${ }^{27}$ appealed to it explicitly in discussing the possible benefits of patronage hiring by state governments:

Party strength requires the efforts of the rank and file, especially in "the dull periods between elections," to perform such tasks as organizing precincts, registering new voters, and providing constituent services. Even the most enthusiastic supporter of a party's program will shrink before such drudgery, and it is folly to think that ideological conviction alone will motivate sufficient numbers to keep the party going through the off years. "For the most part, as every politician knows, the hope of some reward generates a major portion of the local political activity supporting parties.”28

One might argue that this analogy ought not to be extended to the choice of political institutions. With their overtones of exploitation and shortsightedness, factions hardly seem the ideal candidates for shouldering the burden of framing the political rules of the game that govern society. But there is another side to the story. Suppose some business group, seeking to extend the reach of foreign markets for its products, succeeds in pressing for a more open international trading regime? The consumers who benefit from the lower tariffs in such a free trade regime are not likely to fret much even if they were not consulted in its creation. Or suppose that some other faction, wary of being disproportionately burdened by high taxes for foreign military adventures, decides to support stronger constraints on war powers? If such constraints happen to block high-risk and dangerous military engagements, then we may prefer to retain them. What if in both instances the factions succeed in locking in their preferred institutional preferences without significant popular input? In either case it might be imprudent to reverse course simply because the relevant institutional choice was tainted by power and self-interest. Put differently, the implication of factional self-interest in institutional design need not involve a zero-sum dynamic; on the contrary, it might produce a reasonably decent state of affairs. ${ }^{29}$

\footnotetext{
${ }^{26}$ See Cowen et al., supra note 25, at 142.

27497 U.S. 62, 104 (1990) (Scalia, J., dissenting). Admittedly, Justice Scalia is referring to patronage benefits of political parties and not factions, but the broader point is that he alludes to the benefits the self-interests of groups create as a stabilizing force in modern political life. See id.

${ }^{28}$ Id. (citation omitted) (quoting Elrod v. Burns, 427 U.S. 347, 385 (1976) (Powell, J., dissenting)).

${ }^{29}$ Indeed, the fact of the matter is that in a whole range of circumstances the quest for private benefits can be congruent with public goods. For instance, when a middle-class family seeks increased investments in their local public school, they may simply be motivated to further their own children's lifetime opportunities. Nonetheless, they may help produce a social benefit in the form of a more educated citizenry that inures to other members of society.
} 
In the immediate post-Civil War period, for instance, northern Republican factions in the United States deployed their temporary and outsized political leverage to impose their institutional vision on the rest of the country. The end result-an almost complete restructuring of the previous constitutional order in favor of formerly disenfranchised AfricanAmericans-was accomplished without any input from a significant part of the country: the defeated South. As Tom Colby stated in a recent piece:

The Fourteenth Amendment was a purely partisan measure .... [I]t would never have made it through Congress had all of the elected Senators and Representatives been permitted to vote.... [I]t was ratified not by the collective assent of the American people, but rather at gunpoint. ${ }^{30}$

One may tend to think of the Reconstruction Amendments as historical anomalies, but there are a whole host of new institutional regimes that we merely accept because they happen to be. ${ }^{31}$ If such newly created regimes happen to suit our present needs, or at least do not actively undermine them, we may be content to let them persist.

1. What of the Role of Popular Endorsement?.-Perhaps we care not only about whether a good institutional outcome happened to be chosen, but also whether a broad-based majority chose it for the right reasons. But why should we think that an unorganized majority would be motivated to mobilize and seek institutional change in the first place? Indeed, building on Olson's insight about group size, one might argue that an institutional interest that is so broad that it covers every segment of society would be one too diffuse to mobilize. ${ }^{32}$ And while justifications of institutions that are rooted in social contract theories may continue to have some sway in popular discourse, they nonetheless remain unconvincing. It is very difficult, if not improbable, that individuals can come together and create an entire political order from agreement. As Hardin put it, "In a large society, we cannot simply see that we need government and then conclude by creating it. Self-love may block you and me from acting jointly with all our potential fellow citizens." ${ }^{33}$ Of course, once institutional reform is put on the agenda, the voters (or their representatives) may vote up or down as to whether to adopt it either in a referendum or representative assembly, but the contours of such reform are likely to be shaped by others with more skin in the game.

\footnotetext{
30 Thomas B. Colby, Originalism and the Ratification of the Fourteenth Amendment, 107 Nw. U. L. REV. 1627, 1629 (2013).

${ }^{31}$ For illustrations of other such institutions, see infra Part II.A.2-B.

32 See Olson, supra note 4, at 53-55.

33 Russell Hardin, From Power to Order, From Hobbes to Hume, 1 J. PoL. PHIL. 69, 71 (1993).
} 
Moreover, even when institutions are put in place with the best of intentions, they are susceptible to atrophy and neglect if they lack powerful constituencies willing to nourish them. ${ }^{34}$ For instance, Kindleberger argued, about the postwar global institutions, that the patronage of powerful states was indispensable to their survival. ${ }^{35}$ In the early days of the IMF, he observed, "[I]f the United States made no proposal, nothing happened." 36 Another illustration of this dynamic comes from Kenya, where a welldesigned system for registering property eventually collapsed because the commercial interests that used to patronize it no longer found it useful. ${ }^{37}$ In that case, it was not that the registry no longer served a socially useful function, but that the special interest groups that normally invested resources in keeping it afloat lost the will to do so. ${ }^{38}$ And beyond collective action concerns, there are constraints on the ability of citizens to know which political institutions best serve their interests. Compared to policies, for instance, the benefits attainable by alternative political institutions, such as bicameralism, federalism, delegation to international institutions, or the separation of powers, are likely to be even more opaque and hard to understand to ordinary citizens. ${ }^{39}$

To summarize, at the level of the choice of institutions, interests likely matter more than high-minded ideals. But will the institutional options favored by powerful factions come necessarily at the expense of every other group and produce socially wasteful outcomes? Or do collective action problems suggest that political institutions might be undersupplied, and hence the role of self-interested factions might help offset this deficiency? Because there is no widely agreed upon benchmark of an optimal level of political institutions, it is hard to answer these questions in any precise and definitive manner. The bigger challenge is to find an intermediate position between wholesale institutional cooption by factions and complete policy autonomy by institutional actors.

\footnotetext{
${ }^{34}$ See Charles P. Kindleberger, International Public Goods Without International Government, 76 Am. ECON. REV. 1, 10 (1986).

${ }^{35}$ See id.

${ }^{36} \mathrm{Id}$.

37 See Ato Kwamena Onoma, The Contradictory Potential of Institutions: The Rise and Decline of Land Documentation in Kenya, in Explaining Institutional Change: Ambiguity, Agency, AND POWER 63 (James Mahoney \& Kathleen Thelen eds., 2010).

38 See id. at 63-67.

39 See William H. Riker, Six Books in Search of a Subject or Does Federalism Exist and Does It Matter?, 2 COMP. PoL. 135, 135-36 (1969) (discussing the gulf between the robust scholarly debates about federalism and relative public indifference).
} 
In what follows, I will merely try to establish the plausibility that selfinterest can be a benign force for overcoming free riding problems by using an illustration from the founding era.

2. An Illustration from the Philadelphia Convention.-Historically, efforts at centralizing political authority have sometimes been undertaken by factions with an eye towards reducing political transaction costs. ${ }^{40}$ Under the rubric of saving costs, one might include not only the relative ease of concluding political bargains that facilitate commerce across many jurisdictions, but also the need to present a common front in foreign commercial policy.

Bawn et al. have portrayed the Federalists that dominated the Philadelphia Convention agenda in 1787 as a strong and cohesive coalition composed primarily of southern planters and northern mercantilists. ${ }^{41}$ By demolishing the old order under the Articles of Confederation, these two factions were able to collude and set in place a structure that reduced the uncertainty and economic dislocation that resulted from having multiple states trying to regulate and tax cross border transactions. ${ }^{42}$ This new political order was, in Hardin's words, designed "to increase the scale of the market in which entrepreneurs, farmers, and plantation owners in the states could trade.” ${ }^{43}$ To be sure, this arrangement did not benefit those factions that were not powerful enough to register their preferences in this grand bargain. As Hardin observes, "it wrecked the hopes of the AntiFederalist vision of small communities and independent farmers" in full control of their lives and their destinies. ${ }^{44}$ If so, then one has an instance of a factional initiative masquerading as populist democratic reform.

The irony of the Convention is that its success required a political logic that flew in the face of Madison's prescription in Federalist $10 .{ }^{45}$ It

\footnotetext{
40 See, e.g., RUSSEll HaRdin, LIBERAlism, CONSTITUTIONAlisM, AND DeMOCRACY 96 (1999) ("The point [of the 1787 Convention] was not to bargain for any trade in particular but to ease the way to such bargains by eliminating the wasteful transaction costs entailed in interstate tariffs.”).

41 Kathleen Bawn et al., A Theory of Political Parties: Groups, Policy Demands and Nominations in American Politics, 10 PERSP. ON POL. 571, 579-80 (2012).

42 But cf. Robert A. McGuire \& Robert L. Ohsfeldt, Self-Interest, Agency Theory, and Political Voting Behavior: The Ratification of the United States Constitution, 19 AMER. ECON. REV. 219, 232 (1989) (suggesting northern merchants were in general more likely to support the ratification of the Constitution, while southern slave owners were less likely to support ratification).

43 HARDIN, supra note 40, at 95.

44 Russell Hardin, Constitutional Economic Transition, in CONSTITUTIONAL CULTURE AND DEMOCRATIC RULE 333 (John Ferejohn et al. eds., 2001).

45 Madison had argued that an extended republic would better restrain the power of large factions because it would make it harder for them to consolidate their strength. See THE FEDERALIST No. 10, supra note 5, at 58 (James Madison) ("[T] greater number of citizens and extent of territory which
} 
required a national faction that was large and cohesive enough that it could foist its political will on others. ${ }^{46}$ But does that mean that this coalition made a choice that was bad for social welfare or harmful to other groups? Or was the coalition acting more like a dominant corporation that leverages its market power to impose industry-wide product standards, which then benefit other corporations as well? Alternatively, if one prefers the parlance of the realist school of international relations, was it acting like a global hegemon providing an international public good even when the hegemon's motivations might be ostensibly selfish ${ }^{47}$ After all, given the divide and rule policies of the United States' main trading partners in Europe during the post-Revolution Era, it would seem that having a common tariff policy would have provided the young country much needed leverage if it wanted to negotiate favorable commercial terms.

And to have a common tariff, it helps a great deal if one has a central authority that can establish and coordinate tariff policy. But this latter innovation does not imply that such a central authority will choose a socially beneficial tariff; on the contrary, it simply means that if and when a sufficiently powerful enough coalition emerges and wins office, the central authority can impose that coalition's preferred tariffs.

But the challenge with any form of institutional innovation is that it may unintentionally create or exacerbate other social conflicts down the road. And the Philadelphia experiment was no exception. For instance, as early as 1841, the German economist Friedrich List contended that a primary impetus for the Philadelphia Convention was an effort to protect American industry from the postwar flood of cheap English goods. ${ }^{48}$ But when, under the new Constitution, tariffs were eventually slashed in 1816, List accused Congress of being “[c]oerced . . . by powerful private interests

may be brought within the compass of republican than of democratic government ... renders factious combinations less to be dreaded in the former than in the latter.”).

${ }^{46}$ Hardin justifies the stability of the post-Philadelphia constitutional order in similar terms: "[T]he US constitutional order may have come to work in part because one party gained hegemony for several decades. It might not have mattered very much whether the Hamiltonians or the Jeffersonians gained such hegemony. But it might have mattered whether neither had gained it ....” HARDIN, supra note 40, at 239.

47 The proponents of hegemonic stability theory argue that a dominant country that gains disproportionately from an open market will have an incentive to secure and guarantee it for every other state. See, e.g., Kindleberger, supra note 34, at 8-9 (discussing how powerful states provide international public goods); see also Stephen Krasner, State Power and the Structure of International Trade, 18 WORLD POL. 317, 322-23 (1976) (arguing that a "hegemonic state will have a preference for an open structure" because openness "increases its aggregate national income" and "increases its political power").

48 Friedrich List, The National System of Political Economy 77-79 (Sampson S. Lloyd trans., Longmans, Green \& Co. 1909) (1841). 
which were opposed to those of the manufacturers." ${ }^{49}$ Because of the new low tariffs, he argued, "[The United States] suffered, for a second time, greater evils through peace than the most devastating war could have brought upon it." ${ }^{0}$ List's ruminations illuminate the extent to which antifaction rhetoric has been deployed in pursuit of a wide range of purposes in American history. In this case, List used it to impugn the motives of groups seeking free trade. But that does not imply that the protectionist motivations he ascribed to the framing generation were without foundation. Indeed, he himself points to concrete instances where such sentiments were expressed during that period. ${ }^{51}$

List's musings foreshadowed a new fault line of social conflict. The apparent consensus over the need to centralize tariff-making authority in 1787 proved to be somewhat temporary. Sharp disagreements about the scope of tariff-making authority erupted during the antebellum era. ${ }^{52}$ At the heart of these disagreements was a rupture between the two dominant groups that constituted the long coalition in Philadelphia: Southern farmers and Northern mercantilists. Northern mercantilists embraced the view that a tariff could be used to protect infant industries, but export-oriented Southern farmers vehemently opposed this interpretation and thought it could only be used for revenue purposes. ${ }^{53}$ When the infamous Tariffs of Abomination passed in 1828, it eventually spurred the South Carolina Nullification Crisis of $1832 .{ }^{54}$

The institutional politics of the Nullification Crisis defy the conventional wisdom about the relationship between constitutional structure and social welfare. The customary wisdom suggests that institutional structures that encompass bigger geographical entities will be less prone to protectionism than local or more decentralized structures. ${ }^{55}$

49 Id. at 79 .

50 Id. at 80

${ }^{51}$ Id. at 79

52 See Jonathan J. Pincus, Pressure Groups and Politics in Antebellum Tariffs 15-47 (1977); Brian D. Schoen, The Fragile Fabric of Union: Cotton, Federal Politics, and the GLOBAL ORIGINS OF THE CIVIL WAR 100-26 (2009).

53 See SchoEN, supra note 52, at 140-41 (describing the view of many delegates from the Lower South during the Philadelphia Free Trade Convention of 1831 that the protective tariffs were unconstitutional); see also William S. Belko, The Triumph of the ANTEBellum Free Trade MOVEMENT 32-34 (2012).

${ }^{54}$ For a background of this controversy and how it helped set the stage for the civil war, see William W. Freehling, Prelude to Civil War: The Nullification Controversy in South CAROLINA, 1816-1836 (1966).

55 See, e.g., I.M. DESTLER, AMERICAN TRADE POLITICs 32-33, 205-06 (4th ed. 2005) (observing that presidents favored low tariffs because the President's constituency is national while that of a member of Congress is local); Douglas A. IRWIN, FreE Trade Under FIRE 155-57 (2009) (same); E.E. Schattschneider, Politics, Pressures, and the Tariff: A Study of Free Private 
But for John C. Calhoun, the intellectual architect of nullification, it was the preferences of local jurisdictions in the South that would safeguard free trade against the rampant and welfare destroying protectionism of the central government. ${ }^{56}$ Calhoun further understood that courts might not have the capacity or will to distinguish between a constitutionally permissible revenue tariff and an impermissible protective one, ${ }^{57}$ but that export-oriented states like South Carolina—states that were harmed by the protectionist tariffs-would. ${ }^{58}$

The memory of this calamitous event might explain why the framers of the Confederacy rejected the 1787 Constitution as a model for their own legislature's tariff powers. Notably, Article I, Section 8 of the Confederate Constitution included this important qualification: "[N]or shall any duties or taxes on importations from foreign nations be laid to promote or foster any branch of industry; and all duties, imposts, and excises shall be uniform throughout the Confederate States." ${ }^{59}$

The Nullification Crisis of 1832 exemplifies an instance where disagreement about narrow economic interests was strategically elevated to a fundamental contest over the identity and honor of a region. The export value of cotton grew dramatically during the decades before the crisis, and thus the divergence of commercial interests between the agrarian South and the industrial Northeast was magnified. ${ }^{60}$ Both sides took a principled stand in excess of what was at stake in the controversy, namely the reduction or the elimination of the 1828 Tariffs of Abomination. Of course, Calhoun and his political allies might have gambled that raising the stakes was the only political ammunition left for South Carolina to evade the harms of the detested policy. Indeed, after all the posturing, South Carolina immediately

ENTERPRISE IN PRESSURE POLITICS 127-28 (1935) (same); Karen E. Schnietz, The Institutional Foundation of U.S. Trade Policy: Revisiting Explanations for the 1934 Reciprocal Trade Agreements Act, 12 J. POL. HIST. 417, 429, 432 (2000) (same).

${ }^{56}$ See FreEhling, supra note 54, at 156-57 (describing Calhoun's role in the Nullification Crisis).

57 John C. CAlHoun, Rough Draft of What Is Called the South Carolina Exposition, in UNION AND Liberty: The Political Philosophy of John C. Calhoun 313, 314 (Ross M. Lence ed., 1992) ("The courts cannot look in the motives of legislators. They are obliged to take acts by their titles and professed objects, and if these be Constitutional, [courts] cannot interpose their power, however grossly the acts may, in reality, violate the Constitution.”).

58 See Proceedings of the Convention of South Carolina upon the SubJect of NULLIFICATION 15 (Boston, Beals, Homer \& Co. 1832) (“[A]s the power to regulate commerce, conferred expressly for its security, cannot be fairly exerted for its destruction, so neither can it be perverted to the purpose of building up manufacturing establishments - an object entirely beyond the jurisdiction of the Federal Government."). Indeed, the key pronullification faction in South Carolina was called the "States Rights and Free Trade Association." See FrEEHLING, supra note 54, at 224.

59 Confederate Const., art. 1, § 8, cl. 1.

${ }^{60}$ See Schoen, supra note 52, at 102-07. 
overturned the statute once the tariffs were reduced. ${ }^{61}$ One might hope that, given the intensity of the preferences of the pro-free trade coalitions in South Carolina, there might have been ways to accommodate these preferences outside the tactics adopted in 1832. Extreme political brinkmanship certainly has its merits, but one hopes that it is only resorted to when the stakes at issue are much more fundamental, and not simply the kind of economic injuries that could be addressed by tweaking tariff schedules.

In the end, the two dominant coalitions that descended on Philadelphia in 1787 largely achieved their purpose in forging a new political order. The institutional arrangement they put in place demolished the existing state barriers to interstate trade and helped centralize foreign trade authority in a national government. ${ }^{62}$ This new regime succeeded in thwarting some of the most destructive commercial policies among the states under the old order despite the fact that it was a bargain by factions. ${ }^{63}$ Thus, one cannot assume that factions will tend to lobby for political institutions that will harm the general welfare; on the contrary, they may spur the creation of beneficial political institutions. But the Philadelphia experiment did not take place without any glitches. For instance, the details of how the national government would deploy its foreign trade authority were never ironed out completely during the Convention. To be sure, the new Constitution did not mandate the erection of new international trade barriers to protect domestic industries. But by centralizing the tariff power in the central government it made it easier to do so. And when protectionist tariffs were subsequently established in the early years after the Constitution was ratified, they provoked a strong reaction from Southern farmers who were so dependent on free trade. The Nullification Crisis that ensued in 1832 tested the limits of the Philadelphia bargain, but it by no means undermined it. Ultimately, none of the relevant factions at loggerheads during the Nullification Crisis concluded that it was worth reverting back to the pre-1787 order.

\section{B. Generating Spillover Benefits for Other Groups}

Assuming that factions are self-interested and seek institutions to provide them with private goods, might they generate spillover benefits for other groups in society? The distributional approach to institutions may not

\footnotetext{
61 See FREEHLING, supra note 54, at 293-97.

62 See HARDIN, supra note 40, at 241-42; Bawn et al., supra note 41, at 579-980.

63 See, e.g., HARDIN, supra note 40, at 242-43.
} 
sufficiently acknowledge the possibility of positive externalities from the institutional choice of self-interested factions.

Political institutions have an inherently "public" quality that makes it difficult for vested interests to capture the entire benefits of their favored institutional initiatives to the exclusion of other groups. Or, to put it differently, because political institutions tend to shape the outcome of multiple policies, it is difficult to configure them as pure private goods where parties can capture the entire social surplus. ${ }^{64}$ Thus, compared to normal legislation, which can often be tailored to provide very narrow benefits to a vested interest, institutions are less susceptible to outright exclusivity and rivalry - two of the hallmarks of traditional private goods. ${ }^{65}$ But that does not necessarily imply that all groups and citizens will benefit equally from such institutions. On the contrary, some groups may benefit from institutional arrangements, but others may be left worse off. The existence of positive spillovers from an institutional arrangement to certain groups may be contingent; in other words, even if it harms one group today, it may benefit them in the future. But this latter kind of distributional logic is not just an attribute of political institutions, but applies to a whole other range of public goods as well.

A typical illustration of a positive spillover from institutional choice can be gleaned from the contentious politics of federalism in the United States during the mid-twentieth century. Southern segregationists from the Jim Crow era might have pushed for an institutional regime of strong states' rights with the goal of achieving very specific sectional objectives. Nonetheless, they could not subsequently exclude groups favoring gay marriage from taking advantage of the same institution a couple of decades later when they faced threats from a hostile national coalition. ${ }^{66}$ It does not

\footnotetext{
64 Of course, whether all institutional forms may yield spillover benefits to some groups is questionable. One may be able to imagine a scenario where a faction may try to tailor an institutional arrangement such that it is particularistic enough that it will yield only very narrow benefits to which it may exclude other factions and citizens. For instance, it is plausible that a faction may favor asymmetric federalism, in which states that favor its policy objectives have broad policy autonomy, while the states that it dislikes are constrained by the national government. But this outcome is unlikely for a variety of reasons. First, due to the very constraints inherent in factional bargaining, such an asymmetric institutional arrangement is hardly ever going to be adopted. The factions that are disfavored will simply not agree to the bargain. Second, factions tend to select institutional forms they favor from preexisting institutional arrangements, or from slight alterations to those arrangements.

${ }^{65}$ For an introductory discussion of public goods and the elements of exclusivity and rivalry, see WALTER NiCHOLSON \& CHRISTOPHER SNYDER, MiCROECONOMIC THEORY: BASIC PRINCIPLES AND EXTENSIONS 694-95 (11th ed. 2012).

${ }^{66}$ For instance, as commentators have noted, it was conservative interest groups that first tried to expand the conflict over gay marriage to the national level. Donald P. Haider-Markel, Policy Diffusion as a Geographical Expansion of the Scope of Political Conflict: Same-Sex Marriage Bans in the 1990s, 1 ST. POL. \& POL’Y Q. 5 (2001).
} 
matter that these two groups might not share complementary social or economic objectives because the constraints or flexibility afforded by the institutional arrangements could be exploited for both purposes.

Yet another illustration of a positive externality associated with a regime of states' rights comes from William Riker, who, in answer to the question of whether federalism in the United States was worth preserving, famously stated: "[I]f in the United States one approves of Southern white racists, then one should approve of American federalism.” ${ }^{67}$ But years later, Riker would recant, in a way. Describing his own ideological shift from a New Deal sympathizer in the 1950s to a small-government liberal in the 1980s, he averred that the civil rights legislation of the 1960s had altered the political scene: "With the racial dimension of judgment ... removed, it became possible ... to value federalism unambiguously as a deterrent to statism . . . " ${ }^{68}$ Riker's change of heart suggests that institutions that served a morally questionable agenda for certain groups in one era might produce other socially beneficial goals in another.

In any event, when factions seek to co-opt institutions for their benefit, the relevant dynamic is not the one conventionally feared by public choice theorists. Olson worried that interest groups often try to secure policy outcomes in a manner that provides them specific benefits at the expense of voters. ${ }^{69}$ But at the level of factional support for institutions, Olson's insight could be turned on its head. In this picture, narrow factions push for institutions that create spillover benefits for other groups, but they have no mechanism to extract compensation from these free riders. Thus, the dynamic is instead characterized by passive and unorganized groups who benefit from the hard work and sweat of others, but have done little to contribute to the institutional choice in the first place.

By extending the range of beneficiaries of a favored institutional regime, however, factions may unleash a new range of political forces that are vested in keeping the new regime in place. To be sure, there is no mechanism for ensuring that such a self-reinforcing dynamic will persist; indeed, the new institutional move may fizzle out because of lack of broad support, or it may trigger a backlash that mobilizes opposition seeking to undo it. But in many contexts, there are reasons to suppose that institutions once created have a tendency to be relatively durable because changing them will generate significant transition costs.

\footnotetext{
67 William H. Riker, Federalism: Origin, Operation, Significance 155 (1964).

68 WiLliam H. RIKER, THE DEVELOPMENT OF AMERICAN FEDERALISM, at xiii (1987).

69 OLson, supra note 4, at 111-31, 144.
} 
1. An Illustration: Trade Reform in 1934.-The passage of the Reciprocal Trade Agreements Act (RTAA) of 1934 is a classic illustration of how spillover benefits can be gained from institutional change favored by self-interested factions. ${ }^{70}$ The major institutional changes commonly associated with the RTAA include: delegating trade authority from Congress to the President; shifting from the supermajority requirement of the treaty clause to the congressional executive agreements; adopting most favored nations' requirements in multilateral trade agreements; implementing reciprocal reduction of tariffs; and linking together foreign tariff negotiations with domestic tariff reductions in a single piece of legislation with an up-or-down vote. ${ }^{71}$ Together, these innovations have been credited with ushering in an era of liberalization the likes of which had not been known in American commercial history. ${ }^{72}$

But within the Democratic Party, the Southern interests that championed trade reform were likely less motivated by the ideology of free markets than by a desire to secure access to foreign markets for cotton and tobacco. As exporters of primary agricultural products to Europe, Southern farmers often found themselves at loggerheads with protectionist industries concentrated in the Northeast. ${ }^{73}$ These latter interests had helped place Republicans in the White House in twelve of the sixteen presidential elections between the end of the Civil War and the onset of the New Deal. During this period of Republican hegemony, Southern interests and other export-oriented groups were largely thwarted in their efforts to secure low tariffs. ${ }^{74}$ With an ally in the White House in 1934, and majorities in both houses of Congress, the Democratic commercial coalitions set about trying to reshape the future institutional landscape of trade policy in their favor.

70 In 1934, Congress passed the Reciprocal Trade Agreements Act (RTAA), Pub. L. No. 73-316, $\S 350$ (a), 48 Stat. 943 (1934) (codified as amended at 19 U.S.C. § 1351(a) (2012)). The RTAA authorized the President " $[t] o$ enter into foreign trade agreements with foreign governments . . . and ... [t]o proclaim such modifications of existing duties and other import restrictions ... to carry out any [such] trade agreement.” 19 U.S.C. § 1351(a)(1)(A)-(B).

${ }^{71}$ See § 1351(a). For a broad analysis of these innovations, see Michael A. Bailey et al., The Institutional Roots of American Trade Policy: Politics, Coalitions, and International Trade, 49 WoRLD POL. 309, 311, 336-37 (1997).

72 Kenneth W. Dam, The Rules of the Global Game: A New LoOK at US International ECONOMIC POLICYMAKING 40-43, 73-74 (2001); DestLER, supra note 55, at 205-06; IRWIN, supra note 55 , at 220-22.

73 Richard Franklin Bensel, The Political Economy of American Industrialization, 1877-1900, at 125-28 (2000).

${ }^{74}$ During the interwar years, the passage of the Smoot-Hawley Tariff Act (1930) and the FordneyMcCumber Tariff Act (1922) ushered in a new era of aggressive protectionism by Republican-leaning groups; indeed, Smoot-Hawley was largely credited with spawning a wave of tariff wars around the world. See Michael J. Hiscox, international Trade \& Political Conflict: Commerce, COALITIONS, AND MOBILITY 60-61 (2002). 
The institutional reforms favored by these Democratic coalitions had welfare and distributional consequences for both agrarian and industrial groups, as well as consumers. The reforms improved the economic fortunes of Southern agrarian interests, like tobacco and cotton, while also helping specific industries that were export-oriented, such as aircraft, cameras, and automobiles. $^{75}$ The reforms made certain commercial groups worse off, however, such as heavily protected industries like mining, toymakers, textile producers, and scientific instrument manufacturers. ${ }^{76}$ But a key spillover beneficiary of the reform was the unorganized consumer, who gained from the lower prices on imported products. ${ }^{77}$ Ironically, however, although economists almost uniformly agree about the social benefits of free trade, the verdict in popular surveys is less sanguine. ${ }^{78}$ Thus, it is hard to argue that the voting public demanded this state of affairs; on the contrary, it might be better to describe this as a form of institutional altruism that a faction imposed upon the public.

But a more interesting dynamic turns on the subsequent downstream beneficiaries of the RTAA, especially those whom the proponents of the reform did not intend to target. Initially, the reform was politically fragile and might have been reversed if the political circumstances had favored the Republicans in the early years following reform. For instance, the Republican Party platform of 1936 not only vowed to repeal the RTAA, ${ }^{79}$ it also "condemn[ed] the secret negotiations of reciprocal trade treaties without public hearing or legislative approval." ${ }^{80}$ For years prior to the 1940 election, the Republican leaders in the House and Senate overwhelmingly voted for repeal of the RTAA every time it came up for renewal. ${ }^{81}$ By the late 1940s, however, when some of the Republican business constituencies that initially supported repeal eventually became

75 Karen E. Schnietz, The Reaction of Private Interests to the 1934 Reciprocal Trade Agreements Act, 57 INT'L ORG. 213, 222, 227-28 (2003).

${ }^{76}$ See id. at 218.

77 Robert O. Keohane et al., Democracy-Enhancing Multilateralism, 63 INT’L ORG. 1, 10-11 (2009).

${ }^{78}$ IRWIN, supra note 55, at 1 (“' [F]ree trade does not win many popularity contests. Indeed, public opinion surveys in the United States and Europe reveal increasing skepticism about the benefits of international trade and trade agreements.").

${ }^{79}$ See Republican Party Platform of 1936, AM. Presidency Project (2015), http://www.presidency.ucsb.edu/ws/index.php?pid=29639\#ixzz1RR7G6ga4 [http://perma.cc/PBZ6-LJ A6] ("We will repeal the present Reciprocal Trade Agreement Law. It is futile and dangerous. Its effect on agriculture and industry has been destructive. Its continuation would work to the detriment of the wage earner and the farmer.").

${ }^{80}$ See id.

${ }^{81}$ See Douglas A. Irwin \& Randall S. Kroszner, Interests, Institutions, and Ideology in Securing Policy Change: The Republican Conversion to Trade Liberalization After Smoot-Hawley, 42 J.L. \& ECON. 643, 644-45 (1999). 
net exporters, a split emerged among Republican legislators and many decamped from their long-held protectionist positions to embrace free trade. ${ }^{82}$ This intracoalitional split within the Republican Party made it more likely that the constitutional innovations that made the RTAA possible would remain durable.

But buried in these developments lurks a political puzzle. It is standard fare in discussions about international trade policy to assert that protectionists have a clear advantage in overcoming collective action problems because the benefits to such groups are concentrated, whereas the costs to free trade groups are diffuse. ${ }^{83}$ In this picture, however, there are export-oriented constituencies demanding that politicians seek free trade policies, and these politicians responded by conveying concentrated benefits on these groups. These concentrated benefits turned out not to be a deadweight loss to society, but were actually socially efficient.

Additionally, it is not quite correct to suggest that groups favoring free trade suffered from collective action problems at the time of the passage of the RTAA. The pro-free trade Southern National Farmers Alliance was considered "the largest citizen organization of nineteenth century America." ${ }^{84}$ While this sector was not necessarily small in number, its geographical concentration was high, and there is evidence that the benefits from organizing were significant. Indeed, the political prowess of this group and its offshoots were noteworthy, and it was credited for partially spearheading the campaign to constitutionalize the income tax through the Sixteenth Amendment, which had largely anti-tariff implications. ${ }^{85}$

Southern, pro-free trade interests also played an outsized role in influencing the political platforms of the national and state Democratic Parties in the late nineteenth and early twentieth centuries. They also were instrumental in securing the nomination of anti-tariff Democratic presidential candidates, including Presidents Grover Cleveland and

\footnotetext{
82 See id. at 647 ("Senate Republicans voting in 1934 were responsive only to import-competing interests, whereas those voting in 1945 were responsive to both import-competing and export-oriented interests.”).

83 Indeed, the notion that protectionist groups enjoy a special advantage in capturing the policymaking process is often put forth as a justification for the establishment of the World Trade Organization. See Dongsheng Zang, Divided by Common Language: 'Capture' Theories in GATT/WTO and the Communicative Impasse, 32 HASTINGS INT’L \& COMP. L. REV. 423, 424-27 (2009). For other commentary on the capture theory, see DESTLER, supra note 55, at 14, which discusses how protectionist interest groups capture Congress, and Sungjoon Cho, Toward a New Economic Constitution: Judicial Disciplines on Trade Politics, 42 WAKE FOREST L. REV. 167, 182 (2007), which states: "This cognitive factor tends to reinforce a protectionist proclivity in trade politics because it is usually those well-organized interest groups that regularly patronize and thus capture politicians.”

84 EnCyClopedia of THE GREAT Plains 710 (David J. Wishart ed., 2004).

85 See Kimberly J. Morgan \& Monica Prasad, The Origins of Tax Systems: A French-American Comparison, 114 AM. J. SoC. 1350, 1362 (2009).
} 
Woodrow Wilson. ${ }^{86}$ Indeed, President Cleveland's first administration, with its strong free trade platform, coincided with the return to dominance of the Southern wing of the Democratic Party. ${ }^{87}$ By contrast, when Northern Democrats controlled the party from the Civil War through Reconstruction, they were much more ambivalent and divided on the tariff issue. $^{88}$

Other explanations of the RTAA that rely on the preferences of individual institutional actors are unsatisfactory. Take, for instance, the oftrepeated claim that by delegating authority to the President, Congress empowered an actor whose preferences were more free-trade-leaning than that of Congress. ${ }^{89}$ Setting aside the questions about the problematic motivational and normative logic underpinning this argument, ${ }^{90}$ it also depicts a historically inaccurate picture. The delegation of trade authority to the President in 1934 was actually not particularly novel; on the contrary, it was largely imitating an institutional innovation established by Republican protectionist groups in the late nineteenth century. ${ }^{91}$ And prior to the RTAA, people largely did not view delegation as a pro-liberalization measure by free trade coalitions. For the most part, free trade Democrats during that era tended to denounce delegation as an unconstitutional ploy by protectionist Republicans. ${ }^{92}$ Once the shoe was on the other foot,

${ }^{86}$ See Kevin Narizny, Rational Idealism: The Political Economy of Internationalism in the United States and Great Britain, 1870-1945, SECURITY STUD., Spring 2003, at 1, 9 (discussing the role Southern Democrats played in Wilson's electoral victory).

${ }^{87}$ BENSEL, supra note 73, at 474 n.33.

${ }^{88}$ See id. at 125 ("[I]n the industrial states of the East, the Democrats were much more restrained in their opposition to the tariff; many of them even embraced protection.”). As a result of the compromise of 1876, the Democratic Party had once again become a dominant political force in the South, and thus began the southernization of the Democratic Party.

89 See DeSTLER, supra note 55, at 15 (describing delegation to the President as an effort for Congress to overcome one sided pressure of protectionist groups); Bailey et al., supra note 71, at 327 (observing that presidents favored low tariffs because the President's constituency is national while that of a member of Congress is local); Schnietz, supra note 55, at 429, 432 (same); see also David A. Lake, The State and American Trade Strategy in the Pre-Hegemonic Era, 42 INT'L ORG. 33, 38 (1988) (" $[W]$ here the representative element of the state can be best understood as acting in the interests of society, to use Pareto's famous distinction, the executive acts in the interests for society.”).

90 See Bailey et al., supra note 71, at 313-14 (criticizing the lessons-learned approach); David H. Moore, Beyond One Voice, 98 MinN. L. REv. 953 (2014) (criticizing the empirical and normative claims made in favor of presidential primacy in foreign affairs); Nzelibe, supra note 11, at 1226-31 (same).

${ }^{91}$ See Jide Nzelibe, The Illusion of the Free Trade Constitution (2015) (unpublished manuscript) (on file with author) (describing the use of delegation by Republicans in the nineteenth century to achieve protectionist goals).

92 One of those critical Democrats was the young anti-tariff Representative Cordell Hull (D-Tenn.), who, as Roosevelt's Secretary of State, would embrace delegation as a device for rolling back protectionism. See The Tariff Commission and the Flexible Tariff, in 2 EDITORIAL RESEARCH REPORTS, at 399 (1929), available at http://library.cqpress.com/cqresearcher/document.php?id=cqresrre 1929052900\#.Ujy4aZzCa3o [http://perma.cc/KF7G-LREU]. For Cordell Hull's more optimistic view of 
however, and the presidential electoral fortunes of the Democrats started to change in the 1930s, they discovered the wisdom of delegation. Republicans, on the other hand, had a change of heart in the opposite direction..$^{93}$

The notion that the President is predisposed to free trade is empirically suspect. On the contrary, it is more plausible to think that presidential preferences on trade policy are largely shaped by conflict among partisan coalitions. Historically, some of those coalitions have sought to delegate authority because they favored lower tariffs, and sometimes they have sought to delegate because they did not. ${ }^{94}$

In the end, the forces that drove trade reform under the RTAA were not institutional actors operating autonomously or in opposition to special interest groups. On the contrary, much of the credit for reform should be given to the efforts of export-oriented groups of the 1930s, especially Southern farmers. But these pro-reform coalitions were not likely motivated by a high-minded desire to advance the general welfare. Their intended objectives were much more mundane: they were seeking to dismantle the system of tariffs that hurt their access to profitable markets in Europe. But by pursuing their own private interests, they were able to advance institutional arrangements that lowered tariffs domestically and thus benefited the welfare of consumers in the United States.

\section{Factions May Safeguard Against the Concentration of Authority}

In much of the contemporary discourse about factions, there is an implicit assumption that if one purges the influence of special interest groups from the political scene, public officials will be able to diligently pursue publicly minded objectives. But this logic of attaining political benevolence by subtraction contains many problems. First, a politician who listens exclusively to voters might not necessarily be motivated to do what is in the "public interest" because voters might not necessarily be benignly

delegation when he was Secretary of State, see Judith H. Bello, Rising Tides: The Many-Faceted Benefits of Global Trade Liberalization, 93 PROC. AM. SOC. INT’L L. 86, 87-88 (1999).

93 See Republican Party Platform of 1936, supra note 79.

94 To be clear, delegation to the President in the modern era may be more consistent with free trade objectives. But that may be largely an artifact of the reality that modern presidents are prohibited by the post-RTAA multilateral trade regime from raising tariffs unilaterally, although they have leeway to reduce tariffs. This would be consistent with contemporary observations that the pro-free trade party tends to favor delegation (regardless of the President), while the protectionist party tends to oppose delegation (regardless of the President). See Yevgeniy Kirpichevsky \& Phillip Y. Lipscy, Congressional Preferences and the Structure of Delegation: Reassessing the Effect of Divided Government on U.S. Trade Policy 4 (May 20, 2011) (unpublished manuscript) (available at http://ssrn.com/ abstract=1893289 [http://perma.cc/RAS3-KT5B]). 
motivated. ${ }^{95}$ Setting aside the concerns of majority tyranny, the voters might not necessarily be inclined to engage in disinterested judgments of what the best policy might be, and more importantly, they might not be motivated to have their representatives do so either.

Second, aside from voters and factions, there is also the problem that the office holders themselves behave in self-interested ways that may threaten institutional stability. One significant risk is that as suppliers of public policies who also seek to extend their tenures on power, politicians across the different branches of government might actually seek to pursue power as an end in itself. ${ }^{96}$ In addition, some politicians may be tempted to collude with each other, thus denying the voters any of the supposed benefits of institutional competition that inhere in a system of checks and balances. ${ }^{97}$ While institutional self-aggrandizement by certain office holders, such as the President, need not always result in bad policy outcomes, it could lead to greater policy volatility across electoral cycles and to an increase in the level of maximalist policies, which in turn may increase political instability.

Factions, on the other hand, are more likely to act as policy maximizers who tend to view political power largely as a means for achieving other ideological or material objectives. The implication of this dynamic is that factions may sometimes oppose the centralization or accretion of power if they think it is likely to result in policy goals they disfavor, regardless of which party happens to be in power. Therefore, factions can play a role in overcoming collusion by forcing adversity across institutional boundaries, even when officeholders might otherwise prefer not to be in conflict. In this scenario, if members of Congress seek to collude to enhance the power of a sitting president, they might find

95 See JOSEPH A. SCHUMPETER, CAPITALISM, SOCIALISM AND DEMOCRACY 191 (3d ed. 1950); see also ANTHONy McGanN, THE LOGIC OF DEMOCRACY: RECONCILING EQUALITY, DELIBERATION, AND MiNORITY PROTECTION 79 (2006) ("For democracy to have epistemic value, votes have to represent considered judgments of what the correct policy is. However, political philosophers do not get to tell voters how to use their votes.”).

96 As John C. Calhoun writes: "The advantages of possessing the control of the powers of the government, and thereby of its honors and emoluments, are, of themselves, exclusive of all other considerations, ample to divide ... a community into two great hostile parties.” JOHN C. CALHOUN, A DISQUISITION ON GOVERNMENT AND SELECTIONS FROM THE DISCOURSE 14-15 (1953).

97 Indeed, one of the leading theoretical defenses of the separations of powers builds on the key assumption that the various branches will not engage in collusion. Torsten Persson et al., Separation of Powers and Political Accountability, 112 Q. J. ECON. 1163 (1997). But collusion between the political branches is, of course, relatively common in American constitutional law. See, e.g., Clinton v. City of New York, 524 U.S. 417, 448-49 (1998) (declaring unconstitutional legislation that provided the President with line item veto power); see also Jacob E. Gersen \& Adrian Vermeule, Delegating to Enemies, 112 ColuM. L. REV. 2193, 2231-32 (2012) ("Separation of powers controversies and litigation most often involve collusion-agreement between putative institutional rivals in order to take some constitutionally controversial government action.”). 
themselves facing the wrath of a policy-motivated faction whose interests might not be advanced by such collusion.

Take, for instance, the perennial debates in the literature about war powers. A prevailing concern in the American constitutional system is that during periods of united government, Congress does not tend to check the President in national security, and thus there is a greater risk that the President will embark on military engagements without sufficient popular support. Pildes and Levinson have argued, for instance, that judicial review is most valuable during periods of united government where congressional checks on presidential initiatives are weakest. ${ }^{98}$ While their prescription builds on an acceptable empirical generalization about American politics, ${ }^{99}$ it is nonetheless incomplete. Sometimes, factions may decide to deploy institutions strategically to constrain presidential flexibility when an issue is owned by the political opposition, and increase flexibility on their own issues, regardless of which coalition occupies the White House. ${ }^{100}$

Two examples illustrate how, due to factional pressures, members of Congress opposed expansive war powers even during the presidency of a copartisan, or encouraged more expansive war powers on behalf of the President because of pressure from the political opposition.

\section{Conservative Opposition to Presidential Dominance in War}

Powers: 1947-1960.-_President Truman's Cold War rearmament policies and his decision to commit significant resources to defend South Korea alarmed conservative-leaning groups during the early postwar era. ${ }^{101}$

98 See Daryl J. Levinson \& Richard H. Pildes, Separation of Parties, Not Powers, 119 HARV. L. REV. 2312, 2367-68 (2006).

99 See William G. Howell \& Jon C. Pevehouse, Presidents, Congress, and the Use of Force, 59 INT’L ORG. 209, 215 (2005) ("If they take any public stand or introduce any substantive legislation, copartisans in Congress are likely to demonstrate solidarity with their president, authorizing the use of force or appropriating the funds needed to carry it out.”).

100 The analysis here builds on the "issue ownership" theory of partisan competition in which parties try to shape the relevant issue agenda in a political contest in a way that favors those issues in which they have an electoral advantage. As one prominent political scientist observed, "[P]arties do not debate positions on a single issue, but try instead to make end runs around each other on different issues.” William H. Riker, Introduction to AgENDA FoRMATION 1, 4 (William H. Riker ed., 1993). According to this framework, parties cultivate issue-specific reputations and are thus perceived by voters as being more competent at resolving certain policy problems. For the most part, parties tend to own those issues in which the electorate believes they have a special expertise. In the United States, for instance, Democrats have cultivated a better reputation for handling social welfare and health issues, whereas Republicans seem to have an electoral advantage in national security, drugs, and crime. As such, each party has an incentive to focus their campaigns on those issues in which they are perceived to have a leg up on the opposition. See John R. Petrocik et al., Issue Ownership and Presidential Campaigning, 1952-2000, 118 POL. SCI. Q. 599, 601-02 (2003).

101 Truman's Cold War strategy was encapsulated in the National Security Act of 1947, an elaborate piece of legislation that was dubbed by a prominent Cold War historian "the Magna Carta of the national security state.” Michael J. Hogan, A Cross of Iron: HARRY S. TRUMAN AND the ORIGINS OF THE NATIONAL SECURITY STATE 1945-1954, at 24 (1998). 
These conservative constituencies feared that unrestrained defense spending would lead to higher inflation, economic controls, and other fiscal policies that could harm their interests. ${ }^{102}$ Soon enough, disagreements over policy spilled over into disputes about the constitutional allocation of authority. That controversy came to a head in the aftermath of the Korean War, when conservatives roundly criticized Truman for embarking on the conflict without proper congressional authorization. ${ }^{103}$ But Democraticleaning constituencies were more sympathetic to the vision of a President with more flexible authority and a greater assertive role in foreign affairs. ${ }^{104}$ In addition, there were intense disagreements over how the burden of rearmament and war mobilization ought to be allocated, with conservative constituencies sharply criticizing the huge tax burdens triggered by the Korean War. ${ }^{105}$

These disagreements had a much larger political dimension as well. Specifically, conservative-leaning factions tended to depict Truman's vision of a national security state as complementary to an activist welfare state, in which the occasion of mobilizing for war would be used to consolidate the gains of the New Deal. ${ }^{106}$ The possible symbiotic relationship between the politics of guns and butter was not lost on Truman or on Democratic-leaning constituencies, who actively promoted it. ${ }^{107}$

But the conservative antipathy to growing presidential power in national security during the postwar era was not simply a case of partisan aversion by Republicans to Truman's presidency. On the contrary, conservative resistance to the expansion of presidential foreign affairs powers persisted throughout the 1950s, even after the Republicans won the White House in 1953. Sometimes, their strategies for foiling the growth of presidential authority included proposals for formal constitutional change, such as the aborted Bricker Amendment of 1952-1953, which attempted to weaken the President's treaty powers. ${ }^{108}$ Congress voted on this proposal, which Republican senators overwhelmingly supported, during Eisenhower's presidency. Although Eisenhower expressed sympathy with

\footnotetext{
102 See id. at 9-10. (2013).

103 See Jide Nzelibe, Our Partisan Foreign Affairs Constitution, 97 MinN. L. REV. 838, 874-75

104 See HogAN, supra note 101, at 5, 350-51.

105 See id. at 6.

106 Id. at 290-91.

107 See id. at $350-51$.

108 See Duane tananbaum, The Bricker Amendment Controversy: A Test of EISENHOWER's POLITICAL LEADERSHIP (1988) (describing the Bricker Amendment controversy). For a broader discussion of the debates surrounding the Bricker Amendment movement, see Nzelibe, supra note 20.
} 
his copartisans about the dangers of using the treaty power to deal with domestic issues, he sought to avoid the political pressure for an amendment by committing not to sign any human rights treaty while he was in power. ${ }^{109}$

Sometimes, the strategies deployed by conservative groups were more nuanced, such as trying to roll back the notion (endorsed by Truman) that the President could act unilaterally in foreign affairs. Eisenhower often obliged the more conservative wing of the Republican Party by distancing himself from the constitutional and political vision of his predecessor. ${ }^{110}$ Facing pressures from his conservative flank to reduce taxes and defense spending, for instance, Eisenhower slashed the defense budget, but several members of Congress swiftly condemned him for endangering national security. ${ }^{111}$ When the question arose as to whether the United States would intervene on France's behalf in Indochina in 1954, Eisenhower reassured reporters, "[T] $]$ here is going to be no involvement of America in war unless it is a result of the constitutional process that is placed upon Congress to declare it." ${ }^{112}$

While the pressures of the Cold War might have led to both a more assertive role for President Eisenhower in foreign affairs and a more acquiescent Congress, neither occurred. One cannot attribute reluctance on Eisenhower's part to popular sentiment. On the contrary, as Samuel Huntington has shown elsewhere, popular public opinion during the decades after the end of World War II tended to favor a more assertive role of the American military and an increase in military expenditures. ${ }^{113}$ One might argue that Eisenhower's experience as a former military officer

109 Secretary of State Dulles stated during congressional hearings:

[W] hile we shall not withhold our counsel from those who seek to draft a treaty or covenant on human rights, we do not ourselves look upon a treaty as the means which we would now select as the proper and most effective way to spread throughout the world the goals of human liberty to which this Nation has been dedicated since its inception. We therefore do not intend to become a party to any such covenant or present it as a treaty for consideration by the Senate.

Treaties and Executive Agreements: Hearings on S.J. Res. 1 and S.J. Res. 43 Before a Subcomm. of the S. Comm. on the Judiciary, 83d Cong. 825 (1953).

110 See DWIGHT D. EISENHOWER, Special Message to the Congress on the Situation in the Middle East, January 5, 1957, in Public PaPers of the Presidents of the United States: DWight D. EISENHOWER 1957, at 6, 11 (1958). ("Only with [congressional] cooperation can we give the reassurance needed to deter aggression .... .”); see also LOUIS FISHER, PRESIDENTIAL WAR POWER 116 (3d ed., rev. 2013) ("Eisenhower... came to realize it was a serious mistake, politically and constitutionally, to commit the nation to war in Korea without congressional approval.”).

111 Samuel P. Huntington, The Common Defense: Strategic Programs in National POLITICS 234-43 (1961).

112 Fisher, supra note 110, at 104 (quoting Dwight D. EISENHOWER, The President's News Conference of March 10, 1954, in Public PaPers of the PREsidents OF THE United STATES: DWIGHT D. EISENHOWER 1954, at 299, 306 (1960)).

113 See Huntington, supra note 111, at 236-43. 
cautioned against a more aggressive military role. That might be plausible, except that the top military brass in his administration actually favored increased defense expenditures, ${ }^{114}$ and the Chair of the Joint Chiefs of Staff favored military intervention in Vietnam in 1954. ${ }^{115}$ However, a more plausible explanation is that a strong countervailing current of special interests within his party stood to lose if a more dominant and intrusive military role was asserted. At bottom, those factions promoted more active constraints on presidential war powers during the height of the Cold War.

In sum, conservative factions in the post-World War II era tended to associate greater presidential power with the threat of a creeping statism that would be harmful to their core constituencies, regardless of the occupant of the White House.

\section{Liberal Opposition to Repealing the War Powers Resolution:} 1994-1997. - Starting with the fallout of the Vietnam War, the politics of guns and butter took a sharp turn. Progressive Democrats eventually abandoned their longstanding legacy from the 1950s as the war party, and started to welcome greater congressional constraints on war powers. When the Reagan Administration embraced fiscal policies that made the tradeoff between guns and butter explicit, Republicans cemented their modern reputation as the war party. ${ }^{116}$ For many conservatives in the post-Vietnam era, one particular institutional prize loomed large: repealing the War Powers Resolution (WPR). Passed in 1973 over President Nixon's veto, the WPR provides certain procedures that the President has to comply with before he introduces forces into foreign hostilities. ${ }^{117}$ The WPR has since been criticized by a variety of politicians for hampering the President's war making powers. ${ }^{118}$

\footnotetext{
114 HOGAN, supra note 101, at 387-92.

115 John P. Burke \& Fred I. GreEnstein, How Presidents Test REAlity: DeCisions on VIETNAM, 1954 AND 1965, at 48-49 (1989).

116 Here, the assumption is that a state can invest heavily in either "guns" (i.e., defense), "butter" (i.e., production of other social goods), or a combination of both. During the early portion of the New Deal, investments in guns were considered complimentary to investments in butter, whereas after the Vietnam War they became increasingly viewed as substitutes. See IRVING BERNSTEIN, Guns OR BUTTER: THE PRESIDENCY OF LYNDON JOHNSON 535-37 (1996); Benjamin O. Fordham, The Evolution of Republican and Democratic Positions on Cold War Military Spending: A Historical Puzzle, 31 SoC. SCI. HIST. 603 (2007) (describing the Republican position as the war party); Nzelibe, supra note 103, at 870-71 (describing the Left's guns and butter tradeoff).

117 War Powers Resolution, Pub. L. No. 93-148, 87 Stat. 555-56 (1973).

118 For instance, Bob Dole introduced a bill called the Peace Powers Act of 1995, which in his words would "untie the [P]resident's hands in using American forces to defend American interests." Robert J. Dole, 'We Will Continue in Our Drive to Return Power to Our States and Our People,' WASH. Post, Jan. 5, 1995, at A10.
} 
During the Clinton Presidency, hawkish coalitions within the Republican Party gambled on a "Nixon goes to China" logic; ${ }^{119}$ in other words, they calculated that their best opportunity to scrap the WPR was when a Democrat was in the White House. The legislative vehicle for repeal was a 1995 bill by Congressman Henry Hyde, an Illinois Republican. In a speech on the House floor in support of Hyde's bill, House Speaker Newt Gingrich invoked the spirit of bipartisanship:

I rise for what some Members might find an unusual moment, an appeal to the House to, at least on paper, increase the power of President Clinton. ...

$\cdots$

.... [T] ]he American nation needs to understand that as Speaker of the House and as the chief spokesman in the House for the Republican party, I want to strengthen the current Democratic president because he is the President of the United States. ${ }^{120}$

If he intended this appeal for his colleagues in the Democratic Party, it fell on deaf ears. Representative Lee Hamilton (D-Ind.) asked his colleagues to repudiate the invitation because it "sends a signal that we abdicate our power and give it to the President carte blanche." ${ }^{121}$ In a lopsided decision, House Democrats voted 172-23 against the Amendment that would ostensibly have increased the powers of their copartisan in the White House. ${ }^{122}$

\section{Some Cautionary Notes About the Benefits of Faction}

The analysis above has largely bracketed any discussion of the dark side of factions in institutional design, and has instead focused on the sunny side because such a perspective has been largely overlooked in the public law literature. Such an approach is admittedly partial, but the goal here is to provide a counterweight to the conventional hostility to factions rather than engage in any comprehensive analysis.

Nonetheless, one might argue that the illustrations above have depicted an overly benign picture of the influence of factions in shaping

119 As Robert Goodin has argued elsewhere in explaining the logic of the "Nixon goes to China” effect, "If an action is somehow out of character for a particular politician, then, for that reason there are fewer external obstacles to that politician's performing it.” Robert E. Goodin, Voting Through the Looking Glass, 77 AM. POL. SCI. REV. 420, 421 (1983). In this case, Newt Gingrich's position would have been likely criticized harshly as being overly partisan if he was seeking to expand the war powers of a co-Republican in the White House. But such criticism would seem misplaced when he was pushing to expand the presidential powers of a Democrat.

120141 CONG. REC. H5672-73 (daily ed. June 7, 1995) (statement of Rep. Gingrich).

121 Katharine Q. Seelye, House Defeats Bid to Repeal 'War Powers,' N.Y. TimES, June 8, 1995, at A11.

122 See id. 
institutions. To be clear, I am not suggesting that the net effect of this influence is always going to be positive; on the contrary, tradeoffs are involved. The level of enthusiasm associated with factions depends on whether one thinks the expected benefits from institutional energy outweigh the risks of having institutions that may be partially skewed in favor of the most dominant factions. Indeed, even with some of the illustrations above, one could plausibly argue that the role of factions might have sometimes gone too far in one direction. Take, for instance, the account given of the role of factions in opposing the expansion of presidential war powers during the twentieth century. One could contend that such opposition occasionally compromised the ability of the President to react to both pressing security threats and humanitarian crisis or to resolve an ongoing crisis in the most effective manner. ${ }^{123}$ Whether one thinks that state of affairs is good or bad may depend on one's view of the optimal balance between policy flexibility and constraints in national security. But this paper does not purport to evaluate that balance. It merely suggests that if one thinks constraining presidential flexibility in war powers is sometimes important, one has to factor in the potentially positive role of policy-seeking factions, and not simply rely on the empire building ambitions of other institutional actors, such as members of Congress.

Finally, because promoting certain institutional values and certain factional goals are not mutually exclusive endeavors, one ought to be more circumspect about drawing sharp distinctions between factions that may produce good institutional outcomes and those that do not. Take, for instance, the distribution of factions that favored and opposed the Reciprocal Trade Agreement Act of 1934. It might be that the Republican protectionist groups who opposed reform and helped unleash the SmootHawley tariffs in the early part of the 1930s were in one sense counterproductive, especially from the perspective of good trade policy. But the same protectionist groups that dominated the American political landscape for most of the early-to-mid twentieth century have sometimes favored institutions that created significant spillover benefits for other groups. For instance, for reasons that overlap with their pro-tariff leanings, protectionist groups from the Northeast embraced institutional reform in the mid-nineteenth century that most reasonable people would consider to

123 In his memoirs, for instance, Secretary of State Acheson not only argued that Truman's actions in Korea were constitutional, he also suggested that it was politically prudent for Truman to have avoided a congressional resolution because the arduous process of doing so could have "shaken [the] morale of the troops." DEAn ACHeson, Present at the CREATION: My YeARS at the StATE DEPARTMENT 415 (1969). Moreover, he rebuffed the view that a congressional resolution would have softened political criticism if the war became unpopular; after all, he insisted, "Congressional approval did not soften or divert the antiwar critics of Presidents Lincoln, Wilson, and Roosevelt.” Id. 
be benign: the abolition of slavery. ${ }^{124}$ As Rogowski observed, the abolitionist support for protectionism was born of simple economic logic: "Expanding trade, in the labor-scarce Americas, could only have depressed wages; and such a development would in turn have intensified and prolonged slavery." 125

\section{CONCLUSION}

This Essay has attempted to defend the role of powerful factions in both the design and maintenance of institutions in international and constitutional law.

As long as groups have different capacities to mobilize politically, those with superior political resources are likely to have an upper hand in shaping the political rules of the game. But the role of special interest politics in institutional design need not be pathological. On the contrary, the prospect of private benefits going to certain groups may help spur them to create institutions that also benefit unorganized interests. Of course, this argument only suggests that a certain amount of factional self-interest in institutional design is desirable. It also recognizes that the role of selfinterest and power may sometimes be excessive. On balance, the net benefits of self-interested institutional design hinge on whether it is difficult for factions to extract the entire social surplus from their preferred political institutions to the exclusion of other groups.

But if contemporary political institutions exhibit a considerable degree of nonexcludability and nonrivalry, then unorganized groups may gain from those institutions even when they have contributed little to either establishing or maintaining them. It is perhaps too strong to suggest that all political institutions favored by narrow factions will yield spillover benefits that exceed their social costs. But one may find some solace in the likelihood that deeply asymmetric institutions tend not to have much political staying power in the United States political system. While there are understandably impulses to push the growth of the American state or the executive branch in one direction, there are always counteracting forces

\footnotetext{
124 Indeed, some have suggested that protectionism was the key reason why certain groups opposed slavery. See, e.g., Karen Vossler Champion, Comment, Who Pays for Free Trade? The Dilemma of Free Trade and International Labor Standards, 22 N.C. J. INT’L L. \& COM. REG. 181, 222 (1996) (“The United States has worked to end this practice throughout the world since shortly after its own slavery trade was abolished, though probably more for protectionist purposes than to accomplish any strong moral cause.”). That perspective seems somewhat extreme. It is probably more likely that the goals of seeking higher tariffs by northern industrialists happened to be complementary to the objective of ending slavery.

125 Ronald Rogowski, Commerce and Coalitions: How Trade AfFects Domestic Political ALignMENTS 166-67 (1989) (footnote omitted).
} 
who believe that bolstering a more powerful Congress or diffusing power to the states will serve their interests. Ultimately, any political institution that has significant redistributive consequences is prone to sustained attack from those groups it disadvantages, and might eventually crumble or become significantly revised either after multiple electoral cycles or when new oppositional forces are mobilized.

At its core, however, the approach to institutional design endorsed here is obviously nonideal. As a model of political behavior, it is one that is marked by the dynamics of compromise and side-payments, the selfserving strategies and motives of transient interest groups, and sheer political opportunism. Moreover, while it may inhibit the kinds of maximalist policies that are favored by any one faction, it does not guarantee that the political actors will gravitate towards the optimal set of policies from a welfare perspective. At best, it may provide incentives for politicians to avoid bad policies, and more often than not it may induce them toward outcomes that may seem positively unexceptional.

Thus, unlike the bees in Bernard Mandeville's famous fable or the market in Adam Smith's Wealth of Nations, ${ }^{126}$ the "invisible hand" in a model of self-interested institutional design may not necessarily point in the direction of greater efficiency. Instead, it veers towards an objective that is perhaps less rhetorically appealing but no less praiseworthy: moderate institutional stability under a government bound by constraints.

126 See, e.g., Bernard Mandeville, The Fable of the Bees 67 (Phillip Harth ed., Penguin Books 1970) (1724) ("Thus every Part was full of Vice, / Yet the whole Mass a Paradice.”); ADAM

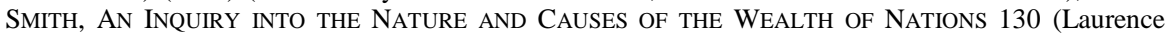
Dickey ed., Hackett Publ'g Co., Inc. abridged ed. 1993) (1776) (“[H]e intends only his own gain, and he is ... led by an invisible hand to promote an end which was no part of his intention. . . . By pursuing his own interest he frequently promotes that of the society more effectually than when he really intends to promote it.”). 
N ORTHW ESTER N U N IVERS ITY L A W R E V IE W 